\title{
THE SAFETY AND EFFICACY OF METHOCARBAMOL AS A MUSCLE RELAXANT WITH ANALGESIC ACTION: ANALYSIS OF CURRENT DATA
}

\author{
H. Jung ${ }^{1 *}$, H.-K. Chae ${ }^{2}$ \\ ${ }^{1}$ SJ Pharma Co., Ltd., Seoul, Republic of Korea \\ ${ }^{2}$ AJU Pharm. Co., Ltd., Seoul, Republic of Korea \\ *Corresponding author: Felix.h.jung@gmail.com \\ Received 15 October 2019; Accepted 12 November 2019
}

\begin{abstract}
Background. The causes of musculoskeletal pain are various diseases of the musculoskeletal system, including osteoporosis, osteochondrosis, arthritis, bone tumors, myalgia, etc. Despite the progress of pharmacology and modern clinical medicine, the problem of pain therapy remains an urgent medical and social problem. One of the preparations of choice for such patients is methocarbomol, a central-acting muscle relaxant whose effect is caused by a general depressant effect on the central nervous system.

Objective. The aim of the work is a critical analysis of current scientific data on the safety and efficacy of the use of methocarbamol as a muscle relaxant mediating analgesic action.

Methods. Analysis and systematization of current scientific data on clinical study of safety and efficacy of methocarbamol preparations in various pathologies.

Results. The results of controlled and uncontrolled clinical trials on the efficacy of methocarbamol have been analyzed, as well as a critical evaluation of data on clinical safety studies.

Conclusions. Methocarbamol is characterized by a favorable safety profile when administered either orally or in injectable form. The incidence of side effects does not exceed that of other commonly used myelorelaxants. Methocarbamol has proven to be an effective and safe drug for use as a supplement to exercise regimen (muscle rest), physiotherapy and other activities to ease the discomfort associated with acute musculoskeletal disorders. Keywords: methocarbamol; pain; myelorelaxant; safety; efficacy.
\end{abstract}

\section{Introduction}

Pain is the most frequent manifestation of the musculoskeletal system diseases, which significantly impairs the quality of life of patients. Diseases of the musculoskeletal system as a cause of disability and mortality are ranked 4th in the world after cardiovascular diseases, cancer diseases and diabetes mellitus (elevated blood sugar level) [1-5]. In Ukraine, approximately 3.5 million people suffer from locomotor system disorders accompanied by musculoskeletal pain [5].

The causes of musculoskeletal pain are various diseases of the locomotor system. Osteoporosis is manifested by pain in the thoracic and lumbar spine, exacerbated after exercise and staying in the same position. One in three postmenopausal women, half of men and older women have osteoporosis $[6,7]$. Degenerative spine disease is the cause of $90 \%$ of the cases of back pain; every 5th individual in the world suffers from back pain [8,9]. The cause of arthritis can be various diseases: arthritis in gout; rheumatoid arthritis, affecting up to $1 \%$ of the world population, is characterized by symmetrical lesions of several joints, which is manifested by pain, swelling, stiffness of movements (mainly in the morning); reactive arthritis (joint lesions in infections of the digestive system and urogenital system) occurs in $0.1 \%$ of the population [10-13]. Osteoarthrosis affects $10-15 \%$ of the global population. The joints of knees, hands, thighs are most often affected by osteoarthrosis [14]. Bone tumors are an uncommon disease. Their prevalence is 3 cases per 100,000 of the population under 15 years of age and 0.2 cases among those aged 30 to 50 years old. Pain is one of the main manifestations of malignant tumors. At the beginning of the disease, the pain is uncertain, and subsequently it is localized in the affected part of the limb and, gradually increasing, becomes permanent [15-18].

Methocarbamol is an ester of carbamic acid, a derivative of guaifenesin carbamate. Pharmacologically, methocarbamol is a central-acting muscle relaxant, the effect of which may be due to a general depressant action on the central nervous system. Sedative and analgesic effects of this agent have also been described. The exact mechanism of action of methocarbamol in humans has not been established. 
It has no direct effect on the contractile mechanism of the striated muscle or motor synapse. Therefore, the drug does not directly relax the skeletal muscle. More likely is its inhibitory effect on polysynaptic reflex activity in the spinal cord, and to some extent also at the superspinal level. Methocarbamol is an effective remedy for lower back or neck pain, fibromyalgia, tension headaches and myofascial pain syndrome [19-22].

The goal of our work was analysis and generalization of actual data on the safety and efficacy of methocarbamol preparations.

\section{Analysis of the results of controlled clinical trials on the efficacy of methocarbamol}

A double-blind study of methocarbamol versus placebo was conducted in 59 patients suffering from painful muscle spasm [23]. Methocarbamol (1500 mg q.d.s. to be taken four times daily) was effective in about $60 \%$ of patients, compared with $30 \%$ of patients receiving placebo ( $p$ less than 0.01 ). Side effects were observed at almost similar frequency in both groups.

Methocarbamol was also investigated in a controlled clinical trial with surgical breast augmentation [24].

One hundred patients with breast augmentation were randomized to one of four treatment groups:

- the group received methocarbamol given in parallel with intercostal nerve blocks;

- the group received methocarbamol without intercostal nerve blocks;

- the group without methocarbamol and with intercostal nerve blocks;

- the group without methocarbamol and without intercostal nerve blocks.

All patients underwent primary breast augmentation without any other procedures. Patients who received intercostal nerve blocks needed as much postoperative pain relievers as those who did not receive the blocks. The latter also did not differ significantly by the visual analog scale scores from those receiving the blocks. Patients who received preoperative methocarbamol had significantly lower pain scores in the first 6 hours after surgery than those who did not $(p=0.03)$.

This study shows that the use of methocarbamol in the experimental groups was associated with lower pain scores during the first 6 hours after surgery. Undesirable side effects of methocarbamol were not reported during the study.
A comparative clinical trial of the efficacy of sodium hyaluronate, methocarbamol and paracetamol in the treatment of stage II Wilke's disease was conducted in 40 patients for 84 days [25]. Sodium hyaluronate has shown somewhat greater efficacy than methocarbamol and paracetamol in the long-term treatment of the disease. Undesirable side effects of methocarbamol were not reported during the study.

A controlled clinical trial of orphenadrine and methocarbamol in pain in the lumbar spine of nontraumatic and non-radicular origin was recently completed [22]. It was conducted during 2015-2018 at Montefiore Medical Center. It was a randomized, placebo-controlled, crossover study. It included 240 patients of both sexes, ages 18 to 69 years old, who referred to this medical center due to acute pain in the lumbar spine of non-traumatic and non-radicular origin that lasted more than 2 weeks. The patients were randomized to three groups: 1) Naproxen (500 mg tablets) twice daily + placebo (placebo dose -1 capsule orally twice daily or 1 or 2 capsules orally, three times daily; Naproxen + placebo was taken for 10 days); 2) Naproxen (500 mg tablets) twice daily + Orphenadrine $(100 \mathrm{mg})$ twice daily for 10 days; 3) Naproxen (500 mg tablets) twice daily + methocarbamol $(750 \mathrm{mg})$ twice daily for 10 days.

The primary criterion for evaluating therapeutic effects was the degree of functional impairment, as assessed by the Roland Morris Disability Questionnaire (assessments were made within a week).

The secondary evaluation criteria were following:

1. The number of cases of moderate or severe pain (assessments were made within a week). Participants with moderate or severe back pain after treatment reported the results on the following pain scale: severe, moderate, mild, or none.

2. Number of patients using analgesics (assessments were made within a week). Number of participants who still had to use analgesics after treatment.

3. Patient satisfaction with treatment [assessments were made within a week]. Number of participants with a positive answer to the following question: "Do you want the same combination of medications to be used in the next episode of lumbar pain?" This is patient-oriented performance that allows each person to determine the desirability of this intervention.

By the primary evaluation criterion, methocarbamol produced a more pronounced therapeutic effect than orphenadrine. Similarly, the methocarbamol group had the lowest number of refusals to continue participating in the trial during the study. 
Another clinical study was conducted on the efficacy of methocarbamol in acute back pain [26]. Muscle relaxants are an important part of the low back pain (LBP) treatment strategy, which is one of the most common problems in industrialized countries. Methocarbamol remains the only explicitly approved muscle relaxant for the treatment of back pain. The use of the drug product in LBP with a myofascial component is well established, although no clinically relevant studies have been published. Therefore, unpublished data on the efficacy of methocarbamol accumulated since 2002 are summarized in this study and re-evaluated [26].

It was a randomized, placebo-controlled, multicenter trial. It included patients who had acute back pain, pelvic/lumbar pain, and impaired mobility for at least 24 hours. Patients received either methocarbamol $(n=98)$ or placebo $(n=104)$. The treatment lasted no more than 8 days, but it could be stopped individually as soon as a persistent analgesic effect was achieved. Individual pain perception was quantitatively assessed using a visual analog scale. Muscle flexibility was determined by the Schober method. In addition, patients and investigators evaluated the efficacy of treatment using a rating scale.

In the treatment group, $44 \%$ of patients completed treatment prematurely because their pain was gone (only $18 \%$ in the placebo group) and $19 \%$ because of lack of efficacy (52\% in the placebo group; $p<0.0001)$. According to muscle flexibility indicators measured using Schober's method, at the end of the study, in the methocarbamol treatment group, $67 \%$ of patients according to the patients' assessments (and only $35 \%$ in the placebo group) and $70 \%$ of patients according to physicians' assessment (and only $35 \%$ in the placebo group) found treatment effective. No serious side effects were identified (7 minor symptoms in 5 patients).
Thus, methocarbamol is an effective and welltolerated therapeutic option for patients with acute low back pain and usually associated mobility limitations.

A clinical placebo-controlled study of the relief of acute musculoskeletal pain with intravenous administration of methocarbamol was conducted [27]. Besides, the following studies were conducted: a controlled study of methocarbamol in acute painful conditions of the musculoskeletal system [24], the effect of this drug product in tetanus neonatorum [28], in the rehabilitation of spastic paresis in pediatric cerebral palsy [29], a comparative study of the efficacy of diazepam and methocarbamol in treatment of back pain [30], in the treatment of cerebral palsy in children [31].

\section{Analysis of the results of uncontrolled clinical trials}

One of the first clinical trials of the original drug product methocarbamol, one of the first "muscle relaxants" for the treatment of back pain, was described in a paper [32]. It was neither randomized nor blind: one group received the drug product (group A) and the other did not (group B) (in a true placebo-controlled study, the second group would have received a tablet without the active agent). In addition, patients' diagnoses were slightly different, as well as the dosage and duration of exposure to the drug. Patients receiving methocarbamol had shorter hospital stays ( 20 days versus 25 days without methocarbamol). The data were not statistically analyzed taking into account their heterogeneity. The dosage regimen of methocarbamol in group A patients is presented in detail in Fig. 1.

Results of the study of the effect of the use of methocarbamol for the treatment of pain in the lumbar spine are shown in Figs. 2, 3.

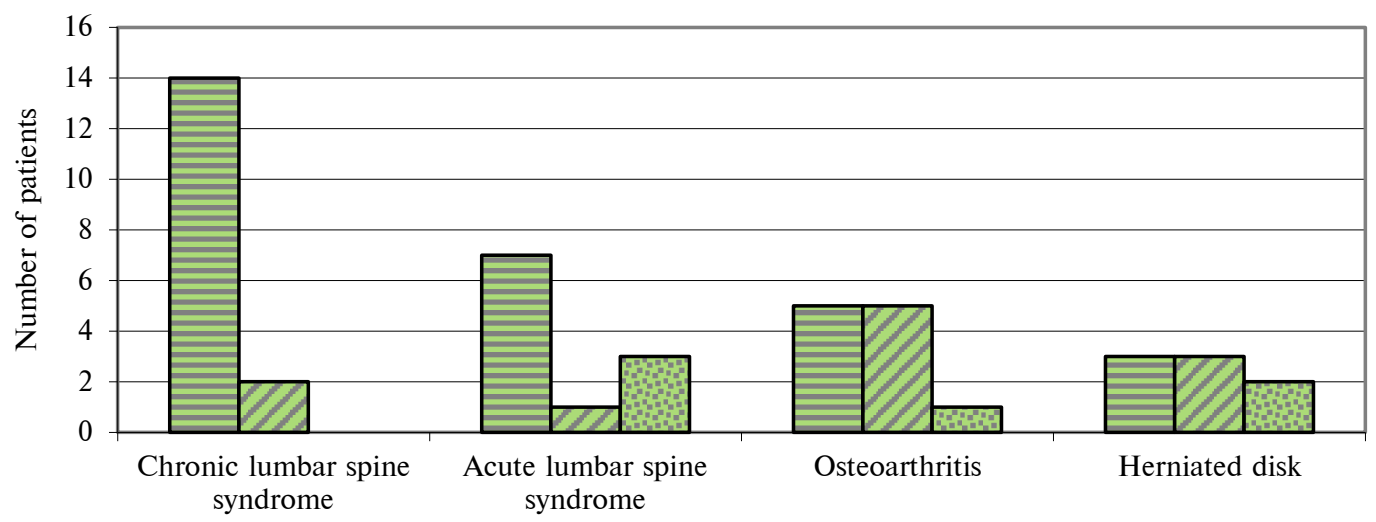

Figure 1: The dosage regimen of methocarbamol for patients group A [32]: $\square-4 \mathrm{~g}$ per day; $\square-6 \mathrm{~g}$ per day; $\square-8 \mathrm{~g}$ per day 


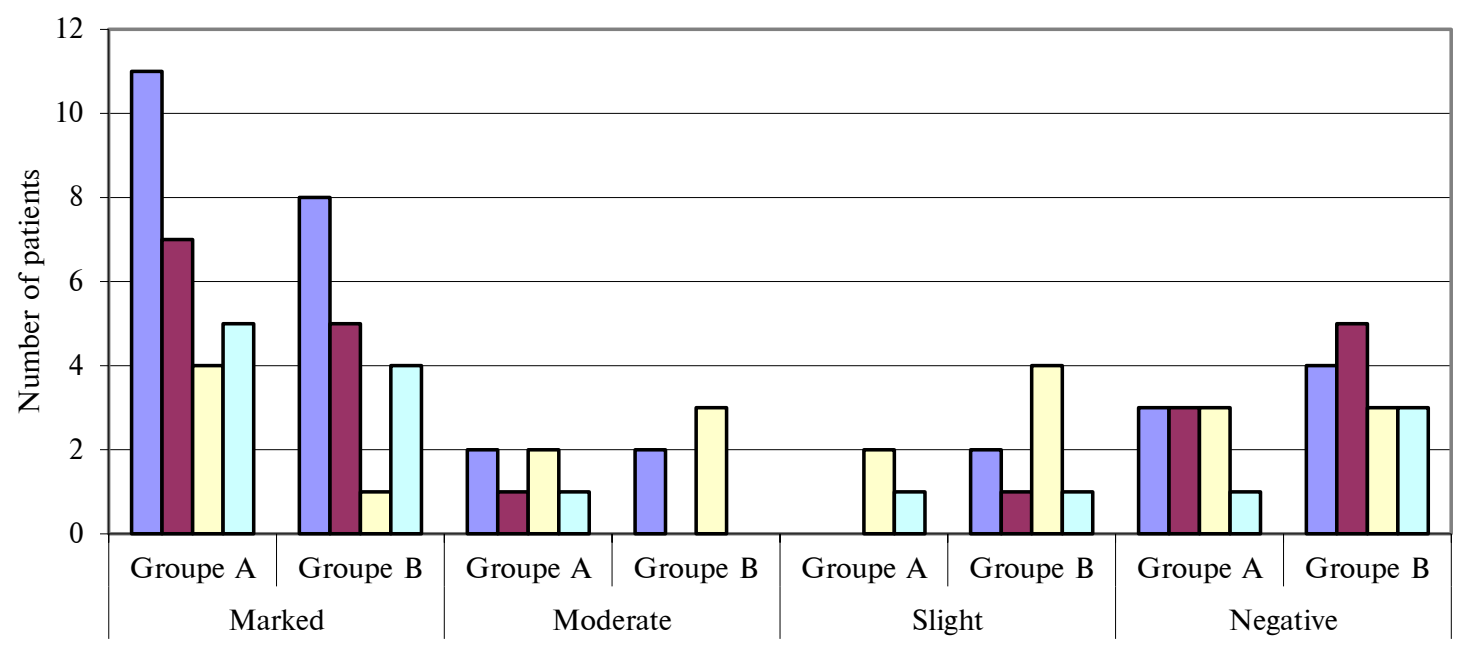

The degree of effectiveness for different groups of patients

Figure 2: Evaluation of the effectiveness of methocarbamol treatment [32]: $\square-$ chronic lumbar spine syndrome; $\square-$ acute lumbar spine syndrome; $\square$ - osteoarthritis; $\square-$ herniated disk

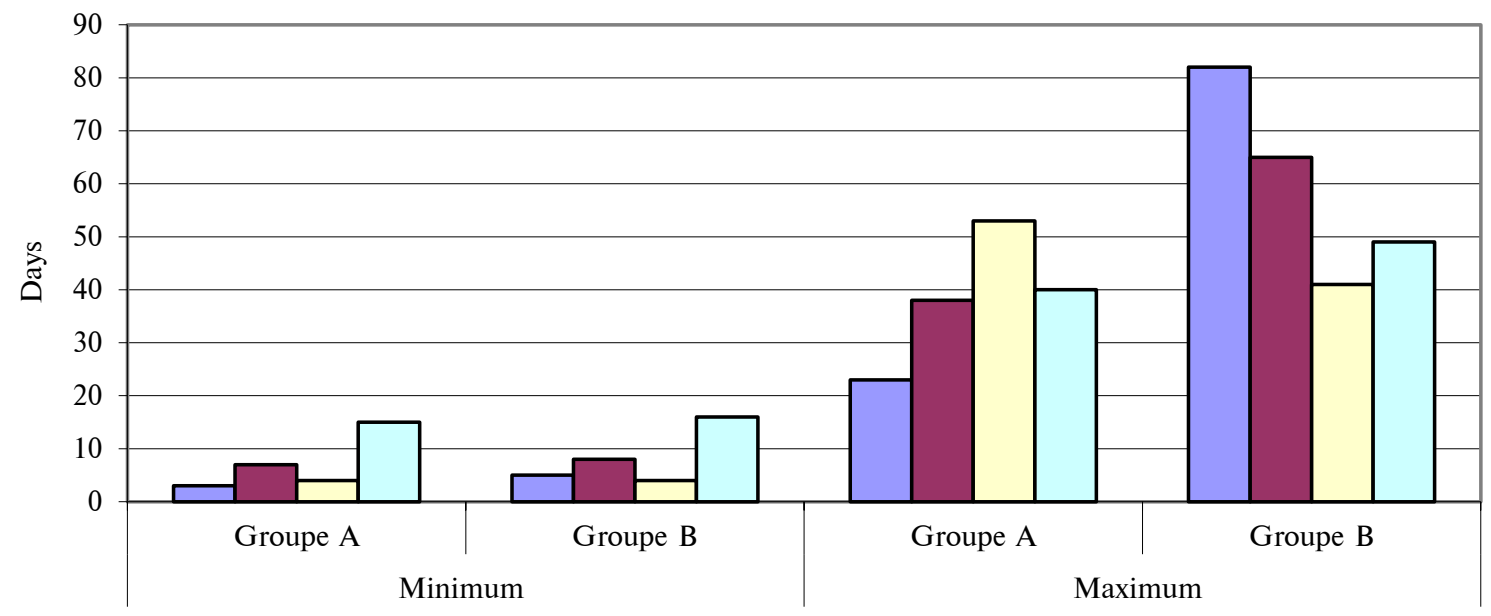

Figure 3: Estimation of the duration of methocarbamol treatment (in days) [32]: $\square-$ chronic lumbar spine syndrome; $\square-$ acute lumbar spine syndrome; $\square-$ osteoarthritis; $\square-$ herniated disk

The study authors conclude that methocarbamol therapy is sufficiently effective for the treatment of low back pain.

A report on the use of methocarbamol in a series of 38 cases has been published [33]. Concerning the evaluation of the results of drug therapy, it should be emphasized that arbitrary muscular disorders are a reflection of disease states, which can be divided into three main categories:

- acute skeletal muscle spasm due to deformity, the muscle itself is the source of pain;

- pathological changes associated with herniation of the spinal cord, where the main complication is radiculitis, skeletal muscle spasm reflexively arises from pressure on the spinal nerve roots;
- disorders of motor function either through the spinal cord or via the supra-spinal path.

A response to medicamental therapy usually varies greatly depending on the diagnosis. A series of clinical cases analyzed consisted of five patients in the first category, two in the second and 31 in the third. A total of 38 patients were treated for the following conditions: multiple sclerosis, lordosis, congenital spastic (right-sided) hemiplegia, acute and chronic spinal cord herniation, paraplegia after tumor removal, acute disseminated encephalomyelitis with paraplegia, residual paralysis after poliomyelitis, severe degenerative hip arthritis, amyotropic lateral sclerosis, lower motor neuron lesions, 
epilepsy, visual impairment, and secondary paraplegia after surgical removal of a neuroma and/or with subsequent arachnoiditis.

The effect of methocarbamol was evaluated clinically. Patients served as their own controls because they were followed-up for periods from weeks to years before the drug product administration. If the effect was highly pronounced, it was rated as "excellent". If the response was obvious but did not reach the level of the first group, it was rated as "good". If the effect of the drug was less pronounced than in the first two groups, it was considered "sufficient". If there was no noticeable response, the term "negative" was used. An excellent response was achieved in $21 \%$ of cases, a good response in $45 \%$, a sufficient response in $16 \%$. The result was negative only in seven cases. In adults, methocarbamol dosages varied from 3 to 6 g per day, and children were offered lower doses.

The following case is typical of those who have had an excellent response. The patient is a 42-yearold woman with paraplegia after surgical removal of neoplastic mass in the area of the third sternal vertebra. She was diagnosed with a dislocation of the left knee, which led to the fall. She also observed poor coordination of the right lower extremity with sharp pain and muscle spasm in the left thigh and below the knee on the left. She was operated with a diagnosis "spinal cord tumor". During the surgery, the tumor was removed at the level of the third and fourth sternal vertebrae. After recovery, the patient noted weakness and severe spasm in the lower extremities. Paresis of all muscle groups was noted in the lower extremities. She received methocarbamol at a dose of 2 tablets $(0.5 \mathrm{~g})$ four times a day for a total daily dose of $4 \mathrm{~g}$. On the fourth day of treatment, it was noted that the spasms became less frequent and less severe. After three weeks of treatment, the dosage was increased to three tablets four times a day $(6 \mathrm{~g})$ and continued at this level for more than two years. During this time the patient was able to keep her legs passively straightened and noted the return of feeling to her toes. The muscle spasms were significantly alleviated, and she was able to actively unflex the left knee and partially flex the left thigh without causing a massive muscle spasm. No abnormalities in urine were detected during therapy. The hemoglobin content in the blood was $13 \mathrm{~g}$ per $100 \mathrm{~cm}^{3}$, and erythrocytes -4.5 per $\mathrm{mm}^{3}$. Leukocyte count was 12,000 per $\mathrm{mm}^{3}-64 \%$ of polymorphonuclear cells and $36 \%$ of lymphocytes.

In the analysis of seven cases where no clinical response was obtained, the following was noted: in one of them there were tension and muscle contractures associated with a history of childhood poliomyelitis.
There were also three cases of multiple sclerosis in this group and one case of probable multiple sclerosis. Another patient showing no response to methocarbamol had secondary hemiplegia with lesion of the brain vessels, and she had complications due to repeated transient vascular episodes in the brain. Also, all muscle groups in her lower extremities showed atrophy. A seven-year-old patient in this group had mild cerebral palsy, but without spasms. His ability to coordinate movements was not enhanced by methocarbamol.

In another clinical trial, 150 patients with involuntarily elevated muscle tone were treated with methocarbamol [34]. Of all patients, there were 42 individuals whose negative symptoms have stabilized.

In total, 150 patients were selected for accurate follow-up of the clinical effect of methocarbamol. All patients included in this study were fully examined prior to treatment. Strength, range of motion, intensity of simple and complex reflexes, motion anomalies, degree of pain and muscle spasm, and other related data were clinically evaluated and recorded. Periodic observations were made after initiation of treatment and after discontinuation of treatment. The therapeutic effect of methocarbamol was classified into three categories: (1) a significant measured response during clinical physical examination; (2) an equivocal response; (3) no significant response. The age ranged from 4 to 72 years with 27 persons in the 25 to 55 year range. The patients were treated at Virginia Medical College Hospital. Duration of treatment ranged from 1 to 135 days, and the total doses per day were from 0.5 to $10 \mathrm{~g}$. The therapeutic effects of methocarbamol are shown in Fig. 4.

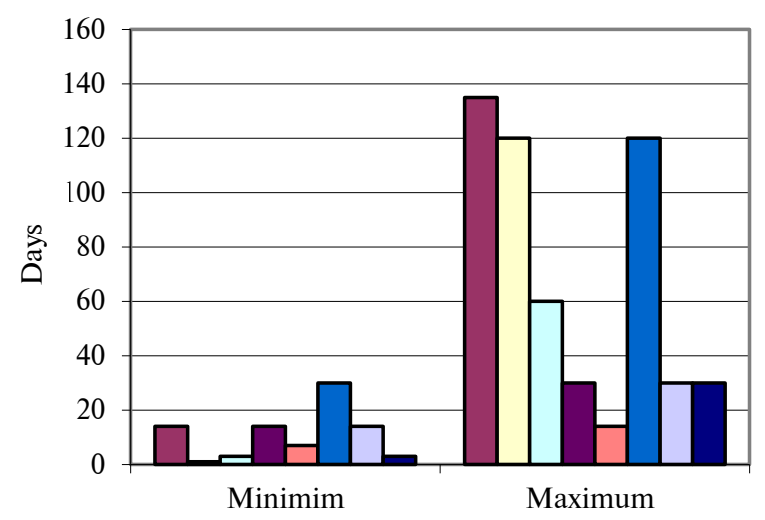

Figure 4: Clinical response of methocarbomol in varios types of disorders (the total number of patients with a specific diagnosis is indicated in parentheses) [34]: $\square-$ spinal cord injury with residual spasticity (11); $\square$ - encephalomyelophathy with residual spasticity (4); $\square$ - cerebrovascular accident with residual spasticity hemiplegia (5); $\boldsymbol{\square}$ - multiple sclerosis (chronic) (2); $\boldsymbol{\square}$ - acute myalgia (idiopathic) (3); $\mathbf{\square}$ - cerebral palsy, spastic paraplegic type (5); $\square$ - cerebral palsy, rotary athetoid type (2); $\mathbf{0}-$ chronic arthritic and myalgia disorders with pain and muscle spasm (10) 
In the group of patients with spinal cord injury and residual spasticity, the final results of treatment differed depending on the severity of the lesions. All patients with complete spinal cord lesions had severe spasticity relapse when treatment was discontinued. Patients with partial impairment retained improved functional ability after completion of methocarbamol treatment course.

In the group of patients with encephalomyelopathy and residual spasticity, there were two patients with tuberculous meningitis, one with influenza meningitis, and one with residual spasticity after prolonged cardiac arrest. All patients had onset of the primary disease more than in 12 months before the study. All had severe generalized spasticity.

Patients with hemiplegia had paralysis for more than nine months. After medicamental treatment with methocarbamol, all showed a clear reduction in the degree of spasticity. In patients with partial paraplegia, the improved function was preserved after discontinuation of treatment.

Each of the patients with multiple sclerosis got this disease more than 10 years ago. The gait defect in all of them was unchanged for more than one year. Methocarbamol treatment led to inhibition of generalized reflex activity, but was withdrawn due to increased instability during treatment.

In the group of patients with acute myalgia, there were two subjects with severe pain and muscle spasm in the lumbar region and inability to stand upright (one case lasting for two days and the other lasting for eight days). All patients were given methocarbamol intravenously at doses of 0.5 to $1.0 \mathrm{~g}$. No objective changes were noted immediately after the intravenous administration, although each patient reported a subjective improvement. Recovery of almost complete movement was observed after 12-18 hours. The muscle spasms disappeared in three to seven days.

Seven patients with well-defined types of cerebral palsy were selected for follow-up. Six patients had a moderate improvement in symptoms during methocarbamol treatment. No objective changes were observed in the patient with athetosis.

A group of patients with chronic arthritis and myalgic disorders with pain and muscle spasm received methocarbamol over a two-week period, but no positive changes were observed.

Methocarbamol was evaluated in 42 patients with various disorders who showed an increase in involuntary muscle tone. In 30 patients with acute myalgic disorders, the use of this drug product resulted in a significant improvement in 27 subjects (90\%). There was a marked improvement in 2 pa- tients, and no effect in 1 patient. No significant improvement resulting from the drug product administration was observed in 12 patients with chronic arthritis, extrapyramidal and myalgic disorders.

Several reviews are devoted to analyzing the efficacy of muscle relaxants, and in particular methocarbamol [35]. Skeletal muscle relaxants are a heterogeneous group of drugs used to treat two different types of underlying conditions: spasm and muscle pain from motor neuron damage or spasms and muscular pain from peripheral musculoskeletal system lesions. Although muscle relaxants are widely used for these indications, there are gaps in our understanding of the comparative efficacy and safety of various skeletal muscle relaxants. A systematic review summarized and evaluated the evidence of the comparative efficacy and safety of skeletal muscle relaxants for the treatment of spasticity and other musculoskeletal disorders. Randomized trials (for comparative efficacy and adverse events) and observational studies (for side effects only), which included drugs classified as musculoskeletal relaxants according to FDA requirements were found using electronic databases, reference lists, and pharmaceutical company submissions. The search was conducted in January 2003. The survey included 101 randomized trials. The results of the analysis indicate that there is very limited or conflicting evidence regarding the efficacy of metaxalone, methocarbamol, chlorzoxazone, baclofen or dantrolene compared with placebo in patients with painful musculoskeletal system conditions. There is insufficient data to determine the relative efficacy and safety of cyclobenzaprine, carisoprodol, orphenadrine, tizanidine, metaxalone, methocarbamol and chlorzoxazone.

Another review states that musculoskeletal relaxants are widely used in the treatment of musculoskeletal system. However, evidence of their efficacy is mainly based on studies with poor methodological design [36]. In addition, these drugs have not been proven to be superior to acetaminophen or nonsteroidal anti-inflammatory drugs in back pain. Systematic reviews and meta-analyzes support the use of skeletal muscle relaxants for short-term relief of acute back pain when non-steroidal anti-inflammatory drugs or acetaminophen are ineffective or are poorly tolerated. Comparative studies have not shown that one muscle relaxant outperforms the other. The best studied one is cyclobenzaprine. The soothing properties of tizanidine and cyclobenzaprine can help patients with insomnia caused by severe muscle spasms. Methocarbamol and metaxalone are less sedative, and their efficacy is limited. 
Negative effects, especially dizziness and drowsiness, have been consistently reported for all muscle relaxants.

In the period from 2010 to 2011 , a retrospective cohort study was conducted in 300 patients, of whom 150 patients received methocarbamol intravenously before knee replacement surgery, and 150 patients did not use this medicinal product [37]. These 2 groups were similar in terms of sex, age, and body mass index. Opioid consumption for anesthesia was evaluated for 48 hours after surgery at 3 separate time intervals, and their total intake for 48 hours. The average use of opiates with intravenous administration of methocarbamol decreased significantly at all time intervals $(6.1 \pm 3.0$ to $7.5 \pm 3.4 \mathrm{mg}$; $p<0.01)$. The progress in physiotherapy with knee flexion, the average duration of the walk and the maximum duration of the walk during rehabilitation significantly improved, and the hospital stay was shorter $(3.6 \pm 1.0$ and $4.0 \pm 1.1$ days $)$. This study demonstrates a significant improvement in postoperative recovery with the use of preoperative intravenous methocarbamol.

According to another clinical study with methocarbamol, good results were obtained in $72 \%$ of patients with acute and chronic muscle spasm [18]. Improvement in all patients with discoordination was noted. Methocarbamol is important in the treatment of muscle spasms and severe flexor spasms that accompany spinal cord lesions, and its use is more limited in the treatment of discoordination.

\section{Analysis of results of clinical safety studies}

The safety of methocarbamol was evaluated in a previously mentioned clinical study [32]. As a result of methocarbamol treatment, such side effects as a skin rash and nausea have been recorded. It is necessary to say, that side effects were recorded in $8.6 \%$ of patients who took part in the clinical trial.

Thus, according to this clinical trial, the use of methocarbamol is safe enough and does not lead to significant undesirable effects.

The safety of methocarbamol was also investigated in another clinical trial in a series of 38 cases [33], mentioned above. Five patients in this trial had mild drowsiness associated with the drug product; in two cases it disappeared when the dosage was decreased, and did not reappear after the initial dosing schedule was restored. Three patients noticed weakness, and one patient reported hyperhidrosis.

Therefore, according to the data of this clinical trial as well, the use of methocarbamol is reasonably safe and does not lead to significant adverse effects.
In the clinical trial [34] discussed above, 150 patients with involuntarily elevated muscle tone were treated with methocarbamol. Of all patients, there were 42 individuals whose negative symptoms were stabilized. No irreversible side effects or toxic effects were found in patients receiving methocarbamol. In two cases, treatment was discontinued due to undesirable side effects. One patient with hemiplegia and mild aphasia had dizziness and drowsiness for 15 minutes after $1.5 \mathrm{~g}$ of methocarbamol. It lasted three days, and treatment was discontinued. About three months later, the patient started with reduced doses of methocarbamol without any side effects. Another patient had recurrent muscle spasms that occurred after poliomyelitis.

About 30 minutes after taking $1.5 \mathrm{~g}$ of methocarbamol, he found it difficult to count. He also complained of a hangover feeling and a dull headache. Methocarbamol treatment was discontinued three days later. Two patients noted side effects when the drug was administered intravenously. One patient had a transient "fuzzy" vision. This condition resolved until the full dose was administered. Another patient had a transient nausea that spontaneously resolved approximately in 30 minutes after administration of methocarbamol. In both patients with multiple sclerosis, ultimate discontinuation of the drug product was due to mild fatigue and increased instability during walking. In all other patients, the side effects were alleviated by a slight dose reduction. No side effects appeared after 72 hours. Following symptoms have been traced in terms of side effects of methocarbamol treatment:

- dizziness in 1 patient;

- drowsiness in 5 patients;

- dull headache in 1 patient;

- easy fatigability in 2 patients;

- headache in 1 in 1 patient;

- inability to concentrate in 1 patient

- increasing unsteadiness of gait in 2 patients;

- transient "fuzzy" vision in 1 patient;

- transient nausea in 1 patient.

In [36], it was noted that musculoskeletal relaxants are widely used in the treatment of musculoskeletal system, but the evidence of their safety is based mainly on studies with poor methodological design. Methocarbamol and metaxalone have less sedative effect than other muscle relaxants, but data on their safety are limited. Negative effects, especially dizziness and drowsiness, have been consistently reported for all muscle relaxants.

A double-blind study of methocarbamol versus placebo was conducted in 59 patients suffering from painful muscle spasm [23]. Methocarbamol (1500 mg) 
was effective in approximately $60 \%$ of patients, compared with $30 \%$ of patients receiving placebo ( $p$ less than 0.01). Side effects were observed at almost the same frequency in both groups.

The side effects of methocarbamol have also been evaluated in a controlled clinical trial of orphenadrine and methocarbamol used in pain in the lumbar spine of non-traumatic and non-radicular origin [22]. No serious side effects of methocarbamol were identified.

In a clinical trial of the safety of methocarbamol in acute back pain [26], no serious adverse events were identified (only 7 minor symptoms were reported in 5 patients).

Another clinical study confirmed that intravenous use of methocarbamol is very well tolerated, except for cases of short-term dizziness [38].

Bioequivalence and safety studies were conducted using two different oral forms of methocarbamol in healthy subjects [39]. It was a single-center, comparative, randomized, open-label, singleuse, two-way crossover study. During it, 32 male or female healthy white volunteers received 2 tablets $(2 \times 750 \mathrm{mg}$ of methocarbamol) or test (a) or reference drug (b) after fasting overnight for at least 12 hours. Breakfast was served in 4 hours after administration of the drugs. The two doses of the drugs were separated by a washout phase of 6 days.

No unexpected non-serious or serious side effects were reported during the study. There were also no clinically relevant findings regarding the effects on vital body functions and ECG parameters.

The effects of administration of diphenhydramine, lorazepam, methocarbamol, and placebo were studied in volunteers with histories of drug abuse, including sedatives/hypnotics [40]. Placebo, diphenhydramine $(100,200$, and $400 \mathrm{mg}$ ), lorazepam ( 1 and $4 \mathrm{mg}$ ) and methocarbamol (2.25 and $9 \mathrm{~g}$ ) were tested in a randomized double-blind crossover study involving 14 subjects. Psychomotor and cognitive performance were assessed daily for up to $5.5 \mathrm{~h}$ after administration of the drugs. The results showed that each of the drug products demonstrated a different profile of influence on the test set of medicines. Lorazepam led to a significant increase in subjects' evaluations of the effect and propensity to take the medication, an increase in sedation rates, and impaired psychomotor scores. Methocarbamol also led to a significant increase in subjects' evaluation of the effect and propensity to take the medication and sedation parameters, but this only resulted in a slight impairment of psychomotor and cognitive activity. Diphenhydramine increased the evaluation of subjects and observers regarding the effects of the drug and sedation rates, but resulted in lower impairment of psychomotor scores than lorazepam.

Another clinical study evaluated the potential for methocarbamol abuse [41]. The personal and behavioral effects of the use of methocarbamol, lorazepam, and placebo were studied in a group of adult male volunteers with history of drug addiction (including sedatives/hypnotics). At the first stage of the study, methocarbamol (up to $12 \mathrm{~g}$ ) was administered to six subjects to determine the appropriate doses. At the second stage, a randomized crossover study involving 14 subjects with placebo, lorazepam $(1,2$, and $4 \mathrm{mg}$ ) and methocarbamol $(2.25,4.5$, and $9 \mathrm{~g})$ was conducted. Psychomotor and cognitive indicators, as well as behavioral responses were measured daily before dosing and $5.5 \mathrm{~h}$ after administration of the drugs. The results showed that both lorazepam and methocarbamol produced statistically significant changes in psychomotor and cognitive performance, although only lorazepam increased the morphine-benzedrine group (MGB) scores. Methocarbamol also increased the studied parameters, indicating the occurrence of dysphoric and other side effects at its high doses. Both drug products impair psychomotor and cognitive performance, with lorazepam generally having a greater effect than methocarbamol. The results show that methocarbamol, at doses well above those used therapeutically, has some potential for human abuse; however, this potential for abuse is likely to be reduced due to concomitant side effects in high doses, and is probably lower than that of lorazepam.

The hemolytic potential of methocarbamol was evaluated in a clinical study [42]. Methocarbamol, a compound related with mephenesin, has a hemolytic potential in vitro. A study was conducted to determine the presence of hemolysis after an intravenous injection. Methocarbamol and its solvent (50\% polyethylene glycol-300) were compared with the solvent itself and with control (normal saline) in high- and low-dose regimens in healthy volunteers. A significant increase in plasma hemoglobin level was detected in 30 min after intravenous administration of methocarbamol or its solvent. The maximum initial plasma hemoglobin level was approximately $10 \mathrm{mg} / \mathrm{dl}$ in volunteers receiving solvent only, and when methocarbamol was added, this figure was only $4 \mathrm{mg} / \mathrm{dl}$. After a 3 -day treatment period, the serum haptoglobin level decreased after administration of high doses of either methocarbamol or solvent. Hemolysis, although it was manifested, however, did not exceed the levels detected under physiological conditions, such as exercise, and comprised only a small part of the usual daily hemolysis of old erythrocytes. 


\section{Conclusions}

Methocarbamol is a central muscle relaxant with sedative properties. It does not directly relax tense skeletal muscles in humans. The mechanism of action is not established, but it is possibly related to the general inhibition of the central nervous system. Its action is manifested by the relief of pain, the reduction of muscle spasm and the increased mobility of the affected muscle. Pain relief is caused by changes in the perception of pain. Unlike neuromuscular blockers, methocarbamol does not affect neural conduction, neuromuscular transmission, and muscle excitability. Methocarbamol exhibits a long blocking effect on polysynaptic reflex pathways at doses that do not substantially alter transmission through monosynaptic reflex arcs and interrupts pathological impulses from areas of muscle lesion. It has no direct effect on the mechanism of contraction of the striated muscles, motor synapses or nerve fibers. Methocarbamol is characterized by a favorable safety profile when administered both per os and by injection. The incidence of side effects does not exceed the rates for other commonly used myelorelaxants. Methocarbamol has proven to be an effective and safe drug for use as an adjunct to the regime of restricted physical activity (muscle rest), physiotherapy and other activities, to relieve the discomfort associated with acute musculoskeletal disorders.

\section{References}

[1] Pincus T, Castrejon I, Yazici Y, Gibson KA, Bergman MJ, Block JA. Osteoarthritis is as severe as rheumatoid arthritis: evidence over 40 years according to the same measure in each disease. Clin Exp Rheumatol. 2019;37 Suppl 120(5):7-17.

[2] Cleveland RJ, Nelson AE, Callahan LF. Knee and hip osteoarthritis as predictors of premature death: a review of the evidence. Clin Exp Rheumatol. 2019;37 Suppl 120(5):24-30.

[3] Dizdarevic A, Farah F, Ding J, Shah S, Bryan A, Kahn M, et al. A comprehensive review of analgesia and pain modalities in hip fracture pathogenesis. Curr Pain Headache Rep. 2019;23(10):72. DOI: 10.1007/s11916-019-0814-9

[4] Aguiar ARSA, Ribeiro-Samora GA, Pereira LSM, Godinho LB, Assis MG. Disability in older adults with acute low back pain: the study Back Complaints in the Elderly - (Brazil). Braz J Phys Ther. 2017;21(5):365-71. DOI: 10.1016/j.bjpt.2017.06.008

[5] Pertsev IM, Khalavka MV, Tamm TI, Datsenko OB, Balanovich MM. Diseases of the musculoskeletal system. Osteochondrosis: prevention, diagnosis, treatment. Apteka [Internet]. 2017 [cited 2017 Feb 17];6(1077).

Available from: https://www.apteka.ua/article/401532

[6] Lizneva D, Yuen T, Sun L, Kim S, Atabiekov I, Munshi LB, et al. Emerging concepts in the epidemiology, pathophysiology, and clinical care of osteoporosis across the menopausal transition. Matrix Biol. 2018;71-72:70-81. DOI: 10.1016/j.matbio.2018.05.001

[7] Yu F, Xia W. The epidemiology of osteoporosis, associated fragility fractures, and management gap in China. Arch Osteoporos. 2019;14(1):32. DOI: 10.1007/s11657-018-0549-y

[8] Moon DK. Epidemiology, cause, and anatomy of osteonecrosis of the foot and ankle. Foot Ankle Clin. 2019;24(1):1-16. DOI: $10.1016 /$ j.fcl.2018.10.001

[9] Olstad K, Shea KG, Cannamela PC, Polousky JD, Ekman S, Ytrehus B, et al. Juvenile osteochondritis dissecans of the knee is a result of failure of the blood supply to growth cartilage and osteochondrosis. Osteoarthritis Cartilage. 2018;26(12):1691-8. DOI: $10.1016 /$ j.joca.2018.06.019

[10] Stewart S, Carroll M, Brenton-Rule A, Keys M, Bell L, Dalbeth N, et al. Region-specific foot pain and plantar pressure in people with rheumatoid arthritis: A cross-sectional study. Clin Biomech (Bristol, Avon). 2018;55:14-17. DOI: 10.1016/j.clinbiomech.2018.04.002

[11] Solmaz D, Eder L, Aydin SZ. Update on the epidemiology, risk factors, and disease outcomes of psoriatic arthritis. Best Pract Res Clin Rheumatol. 2018;32(2):295-311. DOI: 10.1016/j.berh.2018.09.006

[12] Ogdie A, Weiss P. The epidemiology of psoriatic arthritis. Rheum Dis Clin North Am. 2015;41(4):545-68. DOI: $10.1016 / j . r d c .2015 .07 .001$

[13] Queiro R, Lorenzo A, Tejón P, Coto P, Pardo E. Obesity in psoriatic arthritis: Comparative prevalence and associated factors. Medicine (Baltimore). 2019;98(28):e16400. DOI: 10.1097/MD.0000000000016400

[14] Dias IM, Cordeiro PC, Devito KL, Tavares M, Leite IC, Tesch Rde S. Evaluation of temporomandibular joint disc displacement as a risk factor for osteoarthrosis. Int J Oral Maxillofac Surg. 2016;45(3):313-7. DOI: 10.1016/j.ijom.2015.09.016

[15] Priemel MH, Erler JME, Zustin J, Luebke AM, Stiel N, Spiro AS. Histological, epidemiological and anatomical analysis of 193 bone tumours of the scapula. J Bone Oncol. 2019;18:100258. DOI: 10.1016/j.jbo.2019.100258

[16] Khan Z, Gerrish AM, Grimer RJ. An epidemiological survey of tumour or tumour like conditions in the scapula and periscapular region. SICOT J. 2016;2:34. DOI: 10.1051/sicotj/2016023

[17] Loveless MS, Fry AL. Pharmacologic therapies in musculoskeletal conditions. Med Clin North Am. 2016;100(4):869-90. DOI: $10.1016 /$ j.mcna.2016.03.015 
[18] Grodofsky S. Chronic pain in neurosurgery. Anesthesiol Clin. 2016;34(3):479-95. DOI: 10.1016/j.anclin.2016.04.003

[19] British national formulary: BNF 76. 76 ed. London: Pharmaceutical Press; 2018. 1640 p.

[20] Park HJ, Moon DE. Pharmacologic management of chronic pain. Korean J Pain. 2010;23(2):99-108. DOI: 10.3344/kjp.2010.23.2.99

[21] Patanwala AE, Aljuhani O, Kopp BJ, Erstad BL. Methocarbamol use is associated with decreased hospital length of stay in trauma patients with closed rib fractures. Am J Surg. 2017;214(4):738-42. DOI: 10.1016/j.amjsurg.2017.01.003

[22] Friedman BW, Cisewski D, Irizarry E, Davitt M, Solorzano C, Nassery A, et al. A Randomized, double-blind, placebocontrolled trial of naproxen with or without orphenadrine or methocarbamol for acute low back pain. Ann Emerg Med. 2018;71(3):348-56. DOI: 10.1016/j.annemergmed.2017.09.031

[23] Valtonen EJ. A double-blind trial of methocarbamol versus placebo in painful muscle spasm. Curr Med Res Opin. 1975;3(6):382-5. DOI: $10.1185 / 03007997509114791$

[24] Hidalgo DA, Pusic AL. The role of methocarbamol and intercostal nerve blocks for pain management in breast augmentation. Aesthet Surg J. 2005;25(6):571-5. DOI: 10.1016/j.asj.2005.09.003

[25] Oliveras-Moreno JM, Hernandez-Pacheco E, Oliveras-Quintana T, Infante-Cossio P, Gutierrez-Perez JL. Efficacy and safety of sodium hyaluronate in the treatment of Wilkes stage II disease. J Oral Maxillofac Surg. 2008;66(11):2243-6. DOI: $10.1016 /$ j.joms.2008.01.067

[26] Emrich OM, Milachowski KA, Strohmeier M. [Methocarbamol in acute low back pain. A randomized double-blind controlled study]. MMW Fortschr Med. 2015;157 Suppl 5:9-16. DOI: 10.1007/s15006-015-3307-x

[27] Dent RW, Ervin DK. Relief of acute musculoskeletal symptoms with intravenous methocarbamol (robaxin injectable): a placebo-controlled study. Curr Ther Res Clin Exp. 1976;20(5):661-5.

[28] Lall JC, Gupta HL. Therapeutic trial of methocarbamol (Robinax) in tetanus neonatorum. Indian Pediatr. 1975;12(6):503-4.

[29] Ignatowicz R, Gdakowicz B, Kowalczyk K, Zukowska-Walczyk E. Methocarbamol in the rehabilitation of spastic paresis in infantile cerebral palsy. Wiad Lek. 1974;27(17):1546-50.

[30] Robin JP. Comparative study of the value of diazepam and methocarbamol in the treatment of backache. Vie Med Can Fr. $1973 ; 2(5): 442-3$.

[31] Bjerre I, Blennow G. Methocarbamol in the treatment of cerebral palsy in children. Neuropadiatrie. 1971;3(2):140-6. DOI: $10.1055 / \mathrm{s}-0028-1091806$

[32] Grisolia A, Thomson J. A clinical study of 46 males with low-back disorders treated with methocarbamol: a preliminary report from Veterans Administration Hospital, Grand Island, Nebraska. Clin Orthop Relat Res. 1959;13:299-306.

[33] Lewis WB. Use of methocarbamol in orthopedics. Calif Med. 1959;90(1):26-8.

[34] Park HW. Clinical results with methocarbamol, a new interneuronal blocking agent. J Am Med Assoc. 1958;167(2):168-72. DOI: $10.1001 /$ jama.1958.02990190022005

[35] Chou R, Peterson K, Helfand M. Comparative efficacy and safety of skeletal muscle relaxants for spasticity and musculoskeletal conditions: a systematic review. J Pain Symptom Manage. 2004;28(2):140-75. DOI: 10.1016/j.jpainsymman.2004.05.002

[36] See S, Ginzburg R. Choosing a skeletal muscle relaxant. Am Fam Physician. 2008;78(3):365-70.

[37] Looke TD, Kluth CT. Effect of preoperative intravenous methocarbamol and intravenous acetaminophen on opioid use after primary total hip and knee replacement. Orthopedics. 2013;36:25-32. DOI: 10.3928/014774477-20130122-54

[38] Levine IM, Jossmann PB, Rudd J, De Angelis V. The quantitative evaluation intravenous methocarbamol of in the relief of spasticity. Neurology. 1968;18:69-74. DOI: 10.1212/wnl.18.1_part_1.69

[39] Schlegelmilch R, Eydeler AU, Barkworth M, Radeke A. Bioequivalence study with two different oral formulations of methocarbamol in healthy subjects. A mono-centre, comparative, randomized, open-label, single-dose, 2-way crossover study. Arzneimittelforschung. 2009;59(5):238-42. DOI: 10.1055/s-0031-1296391

[40] Preston KL, Wolf B, Guarino JJ, Griffiths RR. Subjective and behavioral effects of diphenhydramine, lorazepam and methocarbamol: evaluation of abuse liability. J Pharmacol Exp Ther. 1992;262(2):707-20.

[41] Preston KL, Guarino JJ, Kirk WT, Griffiths RR. Evaluation of the abuse potential of methocarbamol. J Pharmacol Exp Ther. 1989;248(3):1146-57.

[42] Scott RB, Tisdale SA Jr, Cummings WB. Hemolytic potential of methocarbamol. Clin Pharmacol Ther. 1977;21(2):208-11. DOI: $10.1002 / \mathrm{cpt} 1977212208$

Х. Чунг, Х.-К. Ча

БЕЗПЕКА ТА ЕФЕКТИВНІСТЬ МЕТАКАРБОМОЛУ ЯК МІОРЕЛАКСАНТУ ЗІ ЗНЕБОЛЮВАЛЬНОЮ ДІєЮ: АНАЛІЗ СУЧАСНИХ ДАНИХ

Проблематика. Причинами кістково-м'язових болей є різні захворювання опорно-рухового апарату, зокрема остеопороз, остеохондроз, артрит, пухлини кісток, міальгія тощо. Незважаючи на прогрес фрармакології та сучасної клінічної медицини, проблема 
терапії болю залишається актуальною медико-соціальною проблемою. Одним із препаратів вибору для таких пацієнтів є метокарбомол - міорелаксант центральної дії, ефект якого зумовлений загальним депресантним впливом на центральну нервову систему.

Мета. Критичний аналіз актуальних наукових даних щодо безпеки та ефективності застосування препаратів метокарбомолу як міорелаксанту, що опосередковує знеболювальну дію.

Методика реалізації. Аналіз і систематизація сучасних наукових даних щодо клінічного вивчення безпечності та ефективності застосування препаратів метокарбомолу за різних патологій.

Результати. Проведено аналіз результатів контрольованих та неконтрольованих клінічних досліджень щодо ефективності метокарбомолу, а також критичне оцінювання даних щодо клінічного вивчення безпечності.

Висновки. Метокарбамол характеризується сприятливим профілем безпеки при застосуванні як перорально, так і в ін'єкційній формі. Частота побічних ефектів не перевищує показників для інших часто застосовуваних міорелаксантів. Метокарбамол виявився ефективним і безпечним препаратом для застосування як доповнення до режиму обмеженого фізичного навантаження (м'язового спокою), фізіотерапії та інших видів діяльності, щоб полегшити дискомфорт, пов'язаний із гострими порушеннями опорно-рухового апарату.

Ключові слова: метокарбамол; біль; міорелаксант; безпека; ефективність.

Х. Чунг, Х.-К. Ча

\section{БЕЗОПАСНОСТЬ И ЭФФЕКТИВНОСТЬ МЕТАКАРБОМОЛА КАК МИОРЕЛАКСАНТА С ОБЕЗБОЛИВАЮЩИМ ДЕЙСТВИЕМ: АНАЛИЗ СОВРЕМЕННЫХ ДАННЫХ}

Проблематика. Причинами костно-мышечных болей являются различные заболевания опорно-двигательного аппарата, в частности остеопороз, остеохондроз, артрит, опухоли костей, миалгия и др. Несмотря на прогресс фрармакологии и современной клинической медицины, проблема терапии боли остается актуальной медико-социальной проблемой. Одним из препаратов выбора для таких пациентов является метокарбомол - миорелаксант центрального действия, эффект которого обусловлен общим депрессантным влиянием на центральную нервную систему.

Цель. Критический анализ актуальных научных данных о безопасности и эффективности применения препаратов метокарбомола как миорелаксанта, опосредующего обезболивающее действие.

Методика реализации. Анализ и систематизация современных научных данных клинического изучения безопасности и эффективности применения препаратов метокарбомола при различных патологиях.

Результаты. Проведены анализ результатов контролируемых и неконтролируемых клинических исследований эффективности метокарбомола, а также критическоое оценивание данных клинического изучения безопасности.

Выводы. Метокарбамол характеризуется благоприятным профилем безопасности при применении как перорально, так и в инъекционной форме. Частота побочных эффектов не превышает показателей для других часто применяемых миорелаксантов. Метокарбамол оказался эффективным и безопасным препаратом для применения в качестве дополнения к режиму ограничения физической нагрузки (мышечного покоя), фризиотерапии и других видов деятельности с целью облегчения дискомфорта, связанного с острыми нарушениями работы опорно-двигательного аппарата.

Ключевые слова: метокарбамол; боль; миорелаксант; безопасность; эффективность. 